\title{
ДО ПРОБЛЕМИ РЕЦЕПЦІЇ ПРИНЦИПІВ ЄВРОПЕЙСЬКОГО ПСИХОЛОГІЧНОГО ТЕАТРУ В СЦЕНІЧНОМУ МИСТЕЦТВІ СУЧАСНОГО КИТАЮ
}

У статті здійснено спробу висвітлити особливості рещепщії приниипів європейського психологічного театру в сиенічному мистецтві сучасного Китаю на основі аналізу досвіду кількох провідних театральних діячів України й Російської Федерації, запрошених до роботи в китайських театрах. Висвітлено особливості роботи режисерів над виставою в китайському театрі. Охарактеризовано основні позитивні риси та складнощі у роботі режисерів з китайськими акторами та цехами. Виявлено, щзо китайська розмовна драма тяжіє до школи фіксаиії форми і школи удавання, шляху від зовнішнього до внутрішнього, що було притаманно режисерським системам Вс. Мейєрхольда, Леся Курбаса та інших.

Ключові слова: китайська розмовна драма, Пекінська театральна Академія, китайський театр.

В статье предпринята попытка осветить особенности рецепџии принципов европейского психологического театра в сиеническом искусстве современного Китая на основе анализа опьта нескольких ведущих театральных деятелей Украины и Российской Федерачии, приглашенных для работы в китайских театрах. Освещены особенности работы режиссеров над спектаклем в китайском театре. Охарактеризованы основные положительные черты и сложности в работе режиссеров с китайскими актерами и цехами. Выявлено, что китайская разговорная драма тяготеет к школе фиксаиии формы и школе представления, пути от внешнего к внутреннему, что было характерно для режиссерских систем Вс. Мейерхольда, Леся Курбаса и других.

Ключевые слова: китайская разговорная драма, Пекинская театральная Академия, китайский meamp.

The article attempts to highlight the peculiarities of the European psychological theater principles reception in contemporary Chinese are based on the analysis of experience of several leading theatrical figures of Ukraine and the Russian Federation experience, invited to work in Chinese theaters. The features of the directors' work over the performance in the Chinese theater are highlighted. The main positive features and complexities of directors' work with Chinese actors and workshops are described. It is revealed that Chinese spoken drama tends to the school of fixation of the form and the school of representation, the path from the external to the inner, which was typical for the director systems of Vs. Meyerhold, Les Kurbas and others.

Key words: Chinese Spoken Drama, Beijing Theater Academy, Chinese Theater.

Китайська «розмовна драма», що грунтувалася на запозиченні й адаптації в національному соціокультурному середовищі європейських форм драматичного театру, від початку свого існування природним чином орієнтувалася на західні зразки. Починаючи з середини XX ст. одним з найважливіших орієнтирів стала сформована в СРСР модель психологічного театру з іï ядром, «системою Станіславського». Значення цісї моделі для китайського мистецтва залишається незмінним, попри бурхливі процеси останніх десятиліть: фактичну заборону драматичного театру в період культурної революції, численні експерименти й авангардні пошуки кінця 1970 - початку 1980-х рр., економічний спад, відтік театральних кадрів 1990-х тощо.

Одначе канон психологічного театру в Китаї в процесі його адаптації до місцевих культурних реалій був суттєво переосмислений, відтак його трактування істотно відрізняється від поширеного в Європі. 
Метою пропонованої розвідки є спроба висвітлити особливості рецепції принципів європейського психологічного театру в сценічному мистецтві сучасного Китаю на основі аналізу досвіду кількох провідних театральних діячів України й Російської Федерації, запрошених до роботи в китайських театрах.

Матеріалом для аналізу слугували як опубліковані праці режисерів $[1 ; 2 ; 3]$, так й інтерв'ю, взяті автором $[4 ; 5 ; 6 ; 7 ; 8]$. У фокусі уваги опинилися: Юрій Висоиький (декан факультету театрального мистецтва КНУТКіТ ім. І. Карпенка-Карого), Наталя Колотова (режисер-постановник МДТ, доцент кафедри режисури РДІСМ), Володимир Норенко (професор акторської кафедри РДІСМ), Станіслав Мойсеєв (режисер, керівник акторського курсу КНУТКіТ ім. І. Карпенка-Карого), Володимир Петров (професор школи-студії МХАТ, художній керівник Воронезького академічного театру), які співпрацювали з театральними колективами різних рівнів - від театральної Академії до Пекінського народного художнього театру.

Театральний обмін між європейським і китайським театром, налагоджений на короткий період ще у 1920-х роках, було відновлено й активізовано у середині 1950 -х років після підписання договору про дружбу між КНР і СРСР; це був саме двосторонній процес, спрямований на взаємозбагачення різних культур.

Дещо урізноманітнився склад запрошених для роботи в драматичному театрі Китаю митців наприкінці 1970-х років, коли внаслідок зміни політичного курсу до нашої країни стали приїздити не лише радянські, а й західноєвропейські та американські театральні діячі.

Одним із перших, хто «відкрив вікно» Китаю у театральну культуру західного театру, був Артур Міллер, перший візит якого відбувся восени 1978 року, безпосередньо перед встановленням китайсько-американських дипломатичних відносин. Під час свого візиту Міллер спілкувався 3 багатьма китайськими драматургами, режисерами, акторами й іншими театральними діячами, брав участь у численних зустрічах з китайськими вченими. Повернувшись до США, Міллер видрукував деякі зі своїх подорожніх нотаток у статті під назвою «В Китаї» (The Atlantic Monthly, 1979, № 3). Пізніше він разом із дружиною Інге Мората видав під назвою «Chinese Confounters» свій подорожній фотощоденник.

П'єси Міллера були надруковані в Китаї ще 1962 року, однак це видання вийшло дуже малим накладом. У 1980-ті зроблено переклад творів
А. Міллера «Всі мої сини», «Смерть комівояжера» та інші. Ці видання стали можливими завдяки новій програмі Міністерства освіти, спрямованій на те, щоб «вирватися за попередні обмеження щодо вибору творів, а також сприяти поширенню найвизначніших зарубіжних літературних творів» [9].

1983 року у Народному театрі Пекіна Міллер здійснив постановку власної п'єси «Смерть комівояжера», котра й досі входить до репертуару театру, а наступного року видрукував статтю «Комівояжер у Пекіні», в якій проаналізував культурні відмінності, що виявилися під час роботи над виставою. Ця постановка, на думку літературного критика Ванг Цзулайан, засвідчила, що «у китайських перекладачів гарний смак, у китайських акторів - гарні здібності, а китайський глядач добре відчуває мистецтво і готовий вивчати його нескінченно. Все це дозволяє їм зрозуміти і оцінити всі чудові драми з усього світу» [10]. На думку літературознавця та історика драми У Венькван, вплив Артура Міллера на драматичний театр Китаю як драматурга в цілому, та цієї вистави зокрема, можна визначити у трьох аспектах: «По-перше, дедалі більше й більше китайських трагедій почали мати справу з розчаруванням простих людей. По-друге, реалістичний метод став поглинати експресіоністський “потік свідомості”, що копирсався у внутрішньому світі персонажів. Нарешті, всі прийоми модерного театру, а не лише метод Станіславського, стали широко використовуватися у виставах» [11]. Однак акцент на системі Станіславського залишався незмінним («Станіславський у них бог, і до всіх, хто володіє системою вони ставляться з великим пієтетом і дуже уважно слухають» [5]). Про таке саме ставлення до Станіславського та його ідей свідчить як подальша практика провідних театральних колективів, так і кваліфікаційні вимоги у провідних навчальних закладах у галузі сценічного мистецтва ${ }^{1}$.

Найбільший серед столичних театральних колективів досвід співпраці з іноземними режисерами має Пекінська театральна академія, котра по праву вважається головним центром підготовки майбутніх майстрів театру Китаю. Такий ухил можна пояснити прагненням створити школу психологічного театру в Китаї і налагодити безпосередній діалог не лише між педагогом, який володіє методом Станіславського, і студентом, а й між запрошеним режисером і китайським педагогом,

\footnotetext{
1 Приміром, за період 2008-2017 рр. кількість запрошених режисерів до пекінських театрів із пострадянського простору практично дорівнює сумарній кількості запрошених західноєвропейських та американських режисерів.
} 
прикладом чого може бути досвід Володимира Петрова, який здійснив постановку з викладачами Академії.

Разом із тим, неможливо недооцінювати відмінності, котрі існують між європейською і китайською національною школою. Про специфічність сучасного стану школи психологічного театру в Китаї свідчать відгуки зарубіжних режисерів про китайські вистави. «Драматичний театр, - пише Н. Колотова, - представлено в Китаї в основному одним, незвичним для нас, жанром - "розмовна драма". Назва повністю відображає те, що відбувається на сцені. Актори, одягнені в різні, відповідні до сюжету костюми, ходять, стоять, сидять i... розмовляють. Такий собі візуалізований радіотеатр. Режисерське рішення полягає у спробі 3 більшим або меншим успіхом проілюструвати текст п’єси» $[1,58]$.

Втім, такий занадто загальний та емоційно забарвлений погляд не дає змоги виявити специфіку рецепції традицій реалістичної сцени у драматичному театрі Китаю. На вирішення цього завдання були спрямовані інтерв'ю з режисерами, котрі у різних формах співпрацювали з сучасними театральними колективами, здійснюючи там постановки.

Найменш проблемним елементом роботи над виставою всі запрошені режисери назвали готовність до сприйняття вистави глядачем і роботу зі сценографом - щоправда, 3 певними застереженнями, адже більшість режисерів мала вже готове вирішення вистави: «У мене, - розповідав В. Норенко, - все було вирішено в голові. Зібрали все необхідне ввечері по аудиторіях, і з першої репетиції у мене було все. <...> 3 художником зустрілися два-три рази, і все, але я думаю, що режисер сам повинен придумати, знайти, все сформулювати та представити» [4]. Цього ж принципу дотримується і В. Петров: «3 художником ми працювали до початку репетицій, в основному я сам знаю, що хочу» [5]. Станіслав Мойсеєв, незважаючи на певні складнощі в роботі, також залишився задоволеним співпрацею: «Я розповів, що мені потрібно, запропонував головну ідею, хоча технічно вона й не була реалізована повною мірою. Разом із цим було повне порозуміння» [7].

Серед безумовних труднощів на першому плані, напевно, стоїть проблема особливостей національної театральної школи і культурної традиції, котрі, у поняттях системи Станіславського, безперечно, слід пов'язати 3 театром удавання: «Вони, - згадував В. Петров, - намагаються грати психологічний театр, хоча, коли там ставить китайський режисер, проскакує театр показу “я злякався”, “я зрадів”, є заданість у пластиці» [5]. Для деяких постановників навіть виявилися несподіванкою і система прийомів, на які спирається актор традиційного китайського театру, і система амплуа, що в ньому панує: «В принципі, в Китаї знають, як грати росіян, як грати американців, а решта національностей, так чи інакше, вкладаються в ці два типи. Росіяни зазвичай багато страждають і багато думають. Отже, тон сценічної дії багатозначний і нудний, а ритм майже нульовий. Я з подивом виявила, що і китайським артистам притаманні інтонації, які режисери у нас називають співом. Тобто коли людина не говорить, a інтонує. Коли я зробила зауваження, мовляв, ви не розмовляєте, ви співаєте, перекладачка заступилася: “Це китайська мова, там чотири тони, так китайці розмовляють”. Довелося мені розіграти цілий спектакль, когось розсердити, когось образити, на когось накричати, i треба ж, артисти тут же заговорили своїми голосами, і чотири тони їм зовсім не заважали» $[2,27]$.

Інколи ці традиції істотно впливали на комунікацію між режисером-постановником і акторами: «Головна складність полягала в тому, що на певному етапі прийшов куратор курсу і я просив iii нічого не говорити студентам; коли вона подивилася, то зробила коментар що це все не “по-китайськи", тобто не в традиційній системі штампів (стара жінка має ходити маленькими кроками, приміром), і деякі актори дуже сильно завагалися» [8].

Готовність або неготовність до сприйняття цих особливостей була зумовлена рольовим вибором самого режисера. Адже навіть в обмеженому колі режисерів, які здійснювали вистави у Китаї, виявлено принаймні дві ролі: одна - роль режисеpa, котрий здійснює постановку вистави; інша роль місіонера, котрий має намір прищепити китайському театрові систему Станіславського. Так, скажімо, С. Мойсеєєв вважав, що його завдання «полягало не лише в тому, щоб поставити виставу, мені потрібно було дати їм уявлення про аналіз, адже систему Станіславського їм викладають китайські фахівці, тобто ця система певною мірою перетрактована, і не в напрямі, що наближує, до Станіславського. В застольному періоді я намагався надати їм інформацію про той культурний контекст, що закладений у п’єсі. Практична робота можливо навіть зайняла менше часу, ніж коментар та роз'яснення щодо тих чи інших подій. От, наприклад, навіть на побутовому рівні: їм було дуже складно зрозуміти, як чоловік Васси міг їі 
вдарити. Такі ментальні речі було дуже складно пояснити» [7]. Значною мірою саме ці рольові відмінності визначили і ставлення режисерів до творчих проблем, що виникали у них у процесі репетицій.

Спільною і найголовнішою проблемою всі режисери одноголосно назвали проблему перекладу. Зокрема, це виявляється у процесі спілкування під час репетицій: «Я кажу “сцена брудна”, - згадує Н. Колотова, - А що це таке? Якщо ж я почну пояснювати, що таке “брудна сцена”, я ніколи в житті виставу не поставлю, я тільки й буду 45 днів пояснювати. Мені потрібне було пряме спілкування, а перекладач внутрішньо мені заважав» [6]; таку саму проблему називає і Юрій Висоцький, який розповідає, що «розумів, що мовна проблема буде найголовнішою. Мій перекладач мав режисерську освіту, тому співпраця була дуже плідна. Крім того, я просив, щоб викладач сценічної мови був присутній. Ця практика мала свої результати, і керівництво Академії говорило, що й надалі продовжуватиме такий формат репетицій. Так, звісно, i без слів має бути зрозуміло, що відбувається, але слово, на мій погляд, вкрай важливе» [8].

Причому ці особливості виявлялися не лише на рівні несприйняття метафоричної мови режисера та його завдань, а й у плутанині термінологічній, що змушувало з особливою вимогливістю ставитися до перекладача: «Мені дуже пощастило з перекладачкою, - розповідав В. Петров, - яка вісім років прожила в Москві, тому вона дуже добре розуміла, що і навіщо я роблю. Звісно, це дуже особлива праця, але вони дуже добре слухають. Відучити їх брехати [удавати] можна, навчити їх діяти - можна. На початковому етапі йшла велика редакторська праця [близько двох тижнів], бо переклади це вже “зрадники”, слід було зробити так, щоб мені було зрозуміло, що відбувається» [5].

Однак не всі проблеми вирішувалися за допомогою перекладача. Так, Володимир Норенко змушений був відмовитися від застольного періоду, що було зумовлено складністю спілкування через перекладача; він побудував свою роботу через показ: від показу першої сцени - до невеличкого обговорення [4], що, зрештою, знівелювало саму методологію Станіславського і сприяло радше поширенню зовнішньої форми психологічного театру, а не методу його створення. Адже «проблема, - згадувала Н. Колотова, - не в мовному бар'єрі, хоча перекладати з російської на китайську мову режисерські зауваження складніше, ніж наукову статтю. Проблема в тому, що і російською, і китайською, і будь-якою іншою мовою система Станіславського вимагає вивчення через практику. Не можна прочитати книгу Станіславського (хоча треба прочитати!) або послухати лекцію і вважати, що система у тебе в кишені. <..> Ми, знову ж таки, завдяки Станіславському навчені, перш ніж почати репетирувати, вивчити час дії, місце дії, побут, якщо треба історію держави, тобто зануритися в той світ, який доведеться відтворювати на сцені. I навіть якщо не доведеться, якщо виявиться, що можна зіграти на порожній сцені в уніформі, це нічого не змінює в підході. Щоб відмовитися, потрібно знати, від чого відмовитися. Прийнято читати книги, ходити в музеї, зрештою, заглянути в комп'ютер і знайти там те, що потрібно. Працюючи в Пекіні, я з подивом виявила, що подібного роду підготовчу роботу не робить ніхто. <...>. Включаючи художника-постановника і художника по костюмах. $<\ldots>$ в драматичному театрі немає традиції, немає звички вивчати, що називається, матеріал» $[2,24]$.

Відмова від застольного періоду, своєю чергою, змушувала відмовитися і від етюдного методу («Станіславський, етюдний метод - “з показу” вони працювати могли, все ж таки це був випускний курс. Все, що я хотів зробити з акторами, мені зробити вдалося <...> До етюдного методу (методу дієвого аналізу) навіть гарні актори можуть бути не підготовлені. Були актори, які не могли імпровізувати, але вони при цьому досить пристойні актори - ставиш їм завдання і вони роблять» [4]).

Іншою перепоною у діалозі культур стала проблема культурної традиції і контексту. Інколи це було пов'язано лише 3 конкретними історичними і побутовими реаліями («Якість перекладу впиралася у знання реалій життя, що описує драматург. Я наведу приклад: “Григорій. <..> I знайшла ж кого, буфетного мужика сиволапого! Адже ж ти тільки почала навчатися і з ким зв'язуєшся?” Переклад: “знайшла собі грубого чоловіка з ресторану. Адже ти тільки здобула освіту”» $[2,25])$. Але набагато частіше все було зумовлено загальнокультурним контекстом, світоглядними традиціями тощо.

Поряд із культурними відмінностями, що заважали повноцінній роботі, режисери виявили i ті ознаки, котрі збагатили їхній досвід і варті запозичення. Хоча більшість режисерів працювала над попереднім розподілом ролей через акторське портфоліо (попередньо надсилалися фото- чи відеоматеріали з невеличким коментарем куратора курсу), однак на практиці довелося здійснювати уточнення у процесі репетиційної роботи. Так, Станіслав Мойсеєв кілька днів «витратив на те, 
щоб, спираючись на етюдний метод роботи, здійснити розподіл ролей. Вони [актори] виховані начебто в “системі", але ж зрозуміло, що, насамперед, крізь призму національної ментальності все це трансформовано. Всі спроби грати в психологічний театр для них доволі складні, бо їх все одно тягне до існування в прямолінійних параметрах чорне/біле. Та проте такий кастинг дав мені можливість зробити правильний вибір» [7].

Найбільша проблема виникла 3 найголовнішим етапом роботи над виставою у системі психологічного театру, а саме 3 т. зв. застольним періодом. «У перші дні читки, - згадував Алімов, я став говорити виконавиці ролі Наталки, сестри Нехлюдова: "Вам доведеться співати французьку пісеньку, яку вони співали в дитинстві”. - “Добре, але чому французьку?” - запитала вона. Я почав пояснювати, що в російських дворянських сім'ях першою мовою найчастіше був французька. Два дні читав лекцію на цю тему і не міг пробитися. Вона так і не зрозуміла, чому 3 дитинства розмовляють мовою чужої країни, чому нянька (гувернантка) розмовляє цією мовою. Доводилося просто читати лекції» [3]. Коли стало зрозуміло, що працювати як звично не вийде, згадував Юрій Висоцький, «я намагався підлаштовуватися під те, що пропонували вони. 3 першої читки вони почали “пробувати", не грати характер, а саме пробувати, формат роботи був, я б сказав, “напівпроби”. Але поступово ж треба було зупиняти і щось оговорювати, але спинатися на ноги вони почали 3 першого разу» [8].

Наступну проблему зумовлено особливістю знакових систем, отже, виражальних засобів актора. Приміром, Володимир Петров, розповідаючи про досвід постановки у Китаї, акцентував увагу на іншому інтонаційному словнику. «Театр, - казав він, - це мистецтво інтонації. Кожен час народжує свою інтонацію. Коли ви кажете "I love you", я розумію, маєте ви на це право чи ні. Там інша мова, інші контексти - це складніше відчути. Наче не бреше, а може і бреше, ніби діє, хоча, коли йдеться про дію, тут я ще можу зрозуміти» [5].

Серед традицій, котрі викликали у режисерів заздрість і бажання запозичити їх, всі без винятку постановники називали високий рівень мотивації («Китайські студенти дуже мотивовані під час роботи. Університетська система просто вимагає цього, адже якщо актор протягом року не зіграв у жодній з трьох випускних вистав, він, незважаючи на сплачені кошти за навчання, здані іспити, просто не отримає диплом» [7]).
Мотивація, у свою чергу, впливала на готовність і вміння фіксувати знайдене під час репетиції («Вони достатньо в’їдливі, - вважає В. Петров, - задають багато питань, особливо обдаровані з них. Непогано фіксують. Сдине, що в них $є$ така особливість - якщо вони раптом щось забувають або втрачають якийсь логічний ланцюг, - їх дуже важко потім повернути в необхідне русло» [5]), а також на високий рівень фізичної підготовки: «Зазвичай вони добре підготовлені фізично, хтось займається бойовими мистецтва абощо, але все ж таки рівень їхнього зажиму дуже високий, в порівнянні $з$ нашими студентами вони значно більш зажаті. Рівень володіння словом, враховуючи і їхній національний темперамент, значно кращий» [7]. Водночас цей рівень фізичної підготовки відрізняється від тих особливих вимог, що диктує школа Станіславського. На думку С. Мойсеєва: «Тіло [китайських студентів - Я.Ч.] вимагає розкріпачення» [7]. Цю тезу підтримує i Ю. Висоцький: «Пластична культура наших студентів краща. Там я відчував проблему в танцях, пластичному русі, та й взагалі естетична підготовка студентів мені здається вимагає покращення» [8]).

Загалом режисери, котрі здійснювали постановки у китайському театрі, відзначали незвичний рівень організації репетиційного процесу: «Це був надзвичайно цікавий досвід, у тій роботі було певне зачарування. Вони дуже люблять вчитися і вважають, що вчитися потрібно в усього світу. Для них ті люди, які приїжджають, вони майже священні: приїхав учитель - він нам дає знання. Таке ставлення, звісно, створює особливий внутрішній стан» [7]. Разом із тим, «якоїсь домашньої роботи у них я не відчував, але що важливо - в них немає комплексів, вони вільно та впевнено пробують, дуже демократичні у ставленні один до одного. Однак там потрібна сильна рука: слухати тебе не лише тому, що ти доросліший або приїхав звідкись, вони вимагають доказів» [8].

Втім, деякі режисери відзначали, що, незважаючи на працездатність, китайські актори не завжди здатні витримувати психологічні перевантаження «Мені здавалося, - згадував Юрій Висоцький, - що вони досить високоорганізовані, але ні - демократизм у роботі з китайськими студентами я б не рекомендував. Для них складні були психологічні навантаження, вони не звикли працювати 7-8 годин. Коли педагог годинами працює - вони не готові. В них інший зв'язок “викладач-студент": педагог сказав, і вони пішли самостійно працювати» [8]. Причому цю неготов- 
ність до психологічного перевантаження зумовлено, вочевидь, іншим, незвичним для європейської театральної культури, «рівнем вимог»: «Для Китаю, - вважає Н. Колотова, - робота артиста - це, насамперед, зйомка в рекламі і в нескінченних серіалах. I це - вершина кар'єри. Кіно - 3 галузі фантастики, тому що це справа щасливого випадку. А в драматичному театрі, по-перше, як і всюди, мало вільних місць, по-друге, як і всюди, невелика заробітна плата $<\ldots>$, по-третє, $<\ldots>-$ це доля ентузіастів. Та все це породжує психологію не творця, а виконавця, нехай сумлінного, старанного. <..>> Репетиції в Китаї російської класики територією конфлікту роблять сам підхід до репетиції і до результату репетицій - спектаклю. Бо твори Чехова, Достоєвського, Толстого, Пушкіна, Островського не можна просто добре зіграти. $<$...> Масштаб особистості навіть найбільш негативного або непоказного персонажа настільки вищий від масштабу особистості найстараннішого артиста, що репетиції стають схожі на "американські гірки”, коли режисера кидає то вгору від надії, то вниз від повного відчаю. < ..> перша за значимістю проблема - це вироблення загальних професійних критеріїв» $[2,31]$.

Так само відзначають режисери і недостатню ініціативність у процесі роботи над роллю. «Вони дивляться мені в рот, - згадує Володимир Петров, - і чекають, коли я все їм розповім <..> Ми не створювали виставу разом, в мене не було часу дозволяти їм імпровізувати [репетиції тривали два місяці]. < ..> Коли я кажу, що ти щось робиш, головне питання - чому? Чого ти прагнеш? Яким способом ти до цього прагнеш? Всі ці маркери я їм даю. Це робота гончара. Я все за них вибудовував, а перекладач дуже точно перекладав. Я бачив ескіз вистави, звісно індивідуальність артиста дає про себе знати, але все ж таки я дотримуюсь свого плану, а інакше режисерові ніщо не болить» [5].

Розмірковуючи 3 приводу перспектив оволодіння технікою розмовної драми і системою Станіславського акторами китайського театру, найболючішими місцями режисери вважають «відсутність імпровізаційної школи, потреба працювати над органікою» [5]. Поряд із цим маємо й протилежну думку: «Вони достатньо імпровізаційні. Вони не знають систему, більш того, трепету перед ім'ям Станіславського немає. Вони беруть все корисне, що можуть взяти, але залишаються на своїх позиціях. В їхньому театрі дуже великий елемент яскравої, підкресленої гри, зображення, але вони намагаються поєднати це 3 процесом проживання. Такий баланс» [8]. Не виключено, що такі суперечливі враження зумовлено не особливостями акторської школи Китаю у цілому, а лише особливостями підготовки студентів у конкретному навчальному закладі, конкретним викладачем.

Аналіз постановочної практики кількох провідних українських та російських діячів мистецтва в театрах Китаю дає змогу стверджувати, що в процесі роботи над виставами розмовної драми і впровадження системи Станіславського у режисерів виникали доволі специфічні труднощі, які було зумовлено істотними розбіжностями у культурних традиціях. Так, у культурі Китаю i нині домінує конфуціанське ставлення до традиції та ритуальної повторюваності форми, тому європейська парадигма мистецтва, орієнтована на індивідуальну творчість, залишається для діячів театру Китаю неорганічною. У контексті рецепції принципів європейського психологічного театру (системи Станіславського) в сфері розмовної драми це означає не шлях пошуку, а тяжіння до школи фіксації форми і школи удавання, шлях від зовнішнього до внутрішнього, що було притаманно режисерським системам Вс. Мейєрхольда, Леся Курбаса, а у сучасному театрі - виставам Роберта Вілсона, Ромео Кастелуччі та ін.

\section{Джерела та література}

1. Колотова Н. Китайский набор. Проблемы и преимущества // Театрон. - СПб, СПбГАТИ, 2017. - № 2. C. 57-67.

2. Колотова Н. Тезисы к докладу «Проблемы постановки русской классики на китайской сцене» // Сборник Международной конференции «Запад есть запад? Восток есть восток?» Института Конфуичия в СПбГУ. - СПБ, 2015. - C. 21-31.

3. Романова М. «Воскресение» Л. Н. Толстого на китайской сцене // Иные берега. - СПб, 2016. - № 1. Режим доступу: http://www.inieberega.ru/node/719

4. Інтерв'ю з В. В. Норенко з приводу постановки «Одруження» М. Гоголя в Центральній Академії драми. Санкт-Петербург. - 27.12.2017. - Інтерв'юер Янь Чао // Особистий архів Янь Чао.

5. Інтерв'ю з В. С. Петровим. - Воронеж. - 08.02.2018. - Інтерв’юер Янь Чао // Особистий архів Янь Чао.

6. Інтерв'ю 3 Н. А. Колотовою 3 приводу постановки «Плоди Просвіти» Л. Толстого. - Санкт-Петербург. 26.02.2018. - Інтерв'юер: Янь Чао // Особистий архів Янь Чао.

7. Інтерв”ю з С. А. Мойсеєвим з приводу постановки «Васса Желєзнова» М. Горького в Центральній Академії драми. - Київ. - 26.02.2018. - Інтерв'юер Янь Чао // Особистий архів Янь Чао.

8. Інтерв'ю з Ю. П. Висоцьким з приводу постановки «Тартюф» Ж. Б. Мольєра. - Київ. - 6.02.2018. - Інтерв’юер Янь Чао // Особистий архів Янь Чао.

9. Gu Zhichuan. Replies on the New Senior High School Textbook of Chinese. Режим доступу:

10. http://www.360doc.com/content/11/0328/05/503199_ 105231591.shtml 
11. Huang Zuoliang. The Exciting Performance in May: After Seeing Death of a Salesman // Drama Journal. - 1983. - № 6. - p. 8 .

12. Wu Wenquan, Chen Li, Zhu Qinjuan. Arthur Miller: Reception and Influence in China // The Journal of American Drama and Theatre. - N.-Y., 2015. - Vol. 27, № 3. - C. 1-16.

\section{References}

1. Kolotova, N. (2017). Kitayskiy nabor. Problemyi i preimuschestva // Teatron. - St. Peterburh, SPbGATI. № 2. - S. 57-67 [in Russian].

2. Kolotova, N. (2015). Tezisyi k dokladu «Problemyi postanovki russkoy klassiki na kitayskoy stsene» // Zbornik Mezhdunarodnoy konferentsii «Zapad est zapad? Vostok est vostok?» Instituta Konfutsiya v SPbGU. - St. Peterburh. - S. 21-31[in Russian].

3. Romanova, M. «Voskresenie» L. N. Tolstogo na kitayskoy stsene // Inyie berega. - SPb, 2016. - No. 1. - URL : http:// www.inieberega.ru/node/719

4. Interviu z V. V. Norenko z pryvodu postanovky «Odruzhennia» M. Hoholia v Tsentralnii Akademii dramy (27.12. 2017). -
St.-Peterburh. - Interviuer Yan Chao // Osobystyi arkhiv Yan Chao.

5. Interviu z V. S. Petrovym (08.02.2018). - Voronezh. Interviuer Yan Chao // Osobystyi arkhiv Yan Chao.

6. Interviu z N. A. Kolotovoiu z pryvodu postanovky «Plody Prosvity» L. Tolstoho. - Sankt-Peterburh. - 26.02.2018. Interviuer Yan Chao // Osobystyi arkhiv Yan Chao.

7. Interviu z S. A. Moiseievym z pryvodu postanovky «Vasa Zhelieznova» M. Horkoho v Tsentralnii Akademii dramy (26.02.2018). - Kyiv. - Interviuer Yan Chao // Osobystyi arkhiv Yan Chao.

8. Interviu z Yu. P. Vysotskym z pryvodu postanovky «Tartiuf» Zh. B. Moliera (6.02.2018). - Kyiv. - Interviuer Yan Chao // Osobystyi arkhiv Yan Chao.

9. Zhichuan, Gu. Replies on the New Senior High School Textbook of Chinese. - URL:

10. h t t p : / / w w w. $360 \mathrm{doc}$. c o m / c o n t e nt/11/0328/05/503199 105231591.shtml

11. Zuoliang, Huang (1983). The Exciting Performance in May: After Seeing Death of a Salesman // Drama Journal. - № 6.

12. Wenquan Wu, Li Chen, Qinjuan Zhu (2015). Arthur Miller: Reception and Influence in China // The Journal of American Drama and Theatre. - N.-Y. - Vol. 27, № 3. 